\title{
Photosynthesis gene expression in Rhodobacter sphaeroides is regulated by redox changes which are linked to electron transport
}

\author{
Irene M. Horne, John M. Pemberton and Alastair G. McEwan \\ Author for correspondence: Alastair G. McEwan. Tel: +61 73365 4878. Fax: +61 733654620. \\ e-mail: mcewan@biosci.uq.edu.au
}

Department of

Microbiology, The

University of Queensland,

Brisbane 4072, Australia

\begin{abstract}
The effect of the respiratory electron acceptor nitrous oxide on the synthesis of the photosynthetic apparatus of Rhodobacter sphaeroides was examined. In phototrophically grown cells, the addition of nitrous oxide caused a reduction in the level of light-harvesting complex I and light-harvesting complex II under conditions of high light intensity $\left(200 \mathrm{~W} \mathrm{~m}^{-2}\right.$ ) and low light intensity (16 W $\mathrm{m}^{-2}$ ). 5-Aminolaevulinate synthase activity was decreased during growth in the presence of nitrous oxide and this limited production of spectral complexes since addition of exogenous 5 -aminolaevulinic acid partially suppressed the effect of nitrous oxide. The effect of nitrous oxide on the expression of the operons encoding the pigment-binding proteins of light-harvesting complex 1 (puf), light-harvesting complex II (puc) and the two isoenzymes of 5aminolaevulinate synthase (hemA and hemT) were measured using transcriptional fusions to lacz. Nitrous oxide caused a decrease in puf and hemA transcription. However, there was an apparent increase in the expression of puc and hemt transcriptional fusions. The level of lightharvesting complexes in cells grown in the dark with different electron acceptors was also examined. Cells grown anaerobically with DMSO had a higher level of light-harvesting complexes than those grown anaerobically with nitrous oxide as electron acceptor. Cells grown aerobically had the lowest level of light-harvesting complexes. It is proposed that FnrL-dependent and FnrL-independent expression of photosynthesis genes is modulated by redox changes elicited by nitrous oxide respiration.
\end{abstract}

Keywords: photosynthesis, gene expression, Rbodobacter sphaeroides, anaerobic respiration

\section{INTRODUCTION}

Many species of purple non-sulfur phototrophic bacteria exhibit remarkable bioenergetic versatility. These bacteria are able to respire using oxygen as a terminal electron acceptor, while under anaerobic conditions they can catalyse cyclic photosynthetic electron transfer and respiration with a variety of electron acceptors (McEwan, 1994). Since the pioneering experiments of Cohen-Bazire et al. (1957) it has been established that oxygen represses the formation of the photosynthetic apparatus while under anaerobic conditions the size of the photosynthetic apparatus is inversely related to the incident light intensity (Aagard \& Sistrom, 1972). Rbodobacter sphaeroides and

Abbreviations: ALA, 5-aminolaevulinic acid; Bch, bacteriochlorophyll a; Crt, carotenoids; LH, light-harvesting complex; RC, reaction centre.
Rhodobacter capsulatus have been used as models for investigations of the regulation of the coordinate synthesis of the photosynthetic apparatus (Kiley \& Kaplan, 1988). The photosynthetic apparatus of $R$. spbaeroides contains three distinct pigment-protein complexes involved in the transduction of light energy into electrochemical energy (Kiley \& Kaplan, 1988). Two types of light-harvesting (LH) complex, light-harvesting complex I (LH I or B875) and light-harvesting complex II (LH II or B800-850), are identified by the distinctive absorbance maxima of their bacteriochlorophyll $a(\mathrm{Bch})$ pigments. The core of the photosynthetic unit consists of a reaction centre (RC) surrounded by $10-15$ LH I. The peripheral LH II complex surrounds the $\mathrm{LHI} / \mathrm{RC}$ core and its level increases to a greater extent than LH I upon a reduction in light intensity (Aagard \& Sistrom, 1972).

A cluster of genes on the large chromosome of $R$. 
sphaeroides (Pemberton \& Bowen, 1981; Wu et al., 1991) encodes most of the information required for the synthesis of pigment-binding proteins, Bch and carotenoids (Crt). Many of these genes, including the puf operon (encoding LH I and RC-L and RC-M polypeptides) (Williams $e t$ al., 1983, 1984; Kiley et al., 1987) and the puc operon (encoding LH II polypeptides and assembly proteins) (Kiley \& Kaplan, 1987; Lee et al., 1989) have been sequenced, cis-acting regulatory elements have been identified (Hunter et al., 1991; Lee \& Kaplan, 1992) and detailed studies of mRNA turnover have been made (reviewed by Klug, 1993). Research efforts in this area are now directed towards understanding the mechanism of the control of photosynthesis (PS) gene expression and recently a number of trans-acting factors involved in this process have been identified in R. capsulatus (Sganga \& Bauer, 1992; Buggy et al., 1994; Buggy \& Bauer, 1995) and R. sphaeroides (Penfold \& Pemberton, 1991, 1994; Eraso \& Kaplan, 1994, 1995; Zeilstra-Ryalls \& Kaplan, 1995a). Although considerable progress has been made, the mechanism(s) of light and oxygen sensing in Rhodobacter and the means by which these environmental signals are linked to changes in gene expression are not fully understood. A key question is whether a sensing system detects oxygen directly or acts via redox-induced changes.

Although the presence of anaerobic respiratory pathways in R. sphaeroides and R. capsulatus has been established for a number of years (Ferguson et al., 1987), there is very little information about the effect of anaerobic oxidants on PS gene expression. It was shown that in a denitrifying strain of R. sphaeroides (strain IL106) the presence of nitrate during phototrophic growth caused an approximately twofold decrease in the level of Bch (Michalski \& Nicholas, 1987). A major problem with the interpretation of these data is the complexity of denitrification; nitrate reduction in strain IL106 proceeds via two ubiquinoloxidizing nitrate respiratory pathways while the intermediates of denitrification [nitrite, nitric oxide and nitrous oxide $\left(\mathrm{N}_{2} \mathrm{O}\right)$ ] are reduced via pathways involving the cytochrome $b c_{1}$ complex and cytochrome $c_{2}$ (McEwan, 1994). Furthermore, it is known that nitrite, an intermediate in denitrification, affects both $\mathrm{Crt}$ and $\mathrm{Bch}$ biosynthesis at the enzymic level (Michalski et al., 1985). $\mathrm{N}_{2} \mathrm{O}$ is an attractive tool to overcome the above problems since it is reduced to dinitrogen gas by $\mathrm{N}_{2} \mathrm{O}$ reductase in the last step of denitrification. In this paper the effects of $\mathrm{N}_{2} \mathrm{O}$ on the synthesis of the photosynthetic apparatus are compared to the effect of oxygen and possible mechanisms of electron-transport-dependent control of PS gene expression in R. sphaeroides are discussed.

\section{METHODS}

Bacterial strains and culture conditions. R. sphaeroides strain RS630 (Pemberton \& Bowen, 1981) was grown on RCV minimal medium containing vitamins required for growth of this species (Weaver et al., 1975). For phototrophic growth, cells were grown in completely filled $30 \mathrm{ml}$ screw-cap bottles between banks of tungsten lights. Incident light intensity was calculated as described by Clayton (1970). Addition of DMSO or potassium ferricyanide was made, as required, from a sterile stock solution, to a final concentration of $30 \mathrm{mM}$ and $2.5 \mathrm{mM}$, respectively. For growth in the presence of $\mathrm{N}_{2} \mathrm{O}$, two screw-cap bottles half-filled with RCV medium were sparged with filtersterilized $\mathrm{N}_{2} \mathrm{O}$ from a gas cylinder (Richardson et al., 1991). After inoculation of one screw-cap bottle with a bacterial culture, the second bottle was used to completely fill the first. This procedure was carried out for phototrophic and anaerobic dark growth of $R$. sphaeroides. For aerobic growth of $R$. sphaeroides, $25 \mathrm{ml}$ of cells were shaken (200 r.p.m.) in $250 \mathrm{ml}$ flasks. A $5 \%(\mathrm{v} / \mathrm{v})$ inoculum was used for all experiments and cells were precultured under conditions identical to the experimental conditions. Cells were harvested in late-exponential phase of the bacterial growth curve. Filter-sterilized 5-aminolaevulinic acid (ALA) was added to a final concentration of $5 \mathrm{mM}$ as required. Escherichia coli was grown at $37^{\circ} \mathrm{C}$ in LB medium (Sambrook et al., 1989). Spectinomycin was added where necessary to a final concentration of $25 \mu \mathrm{g} \mathrm{ml}^{-1}$.

Genetic manipulations. Plasmids pCF200 (Lee \& Kaplan, 1992) $\left(\mathrm{Sm}^{\mathrm{r}} / \mathrm{Sp}^{\mathrm{r}} \mathrm{Tc}^{\mathrm{r}}\right.$ IncQ, puc (URS + DRS) : : lac $\left.Z Y A^{\prime}\right)$, pUI1830 (Gomelsky \& Kaplan, 1995) ( $\mathrm{Sm}^{\mathrm{r}} / \mathrm{Sp}^{\mathrm{r}} \mathrm{Tc}^{\mathrm{r}}$ IncQ, pufB:: lacZY $A^{\prime}$ ), pUI1063 (Zeilstra-Ryalls \& Kaplan, 1995a) $\left(\mathrm{Sm}^{\mathrm{r}} / \mathrm{Sp}^{\mathrm{r}} \mathrm{Tc}^{\mathrm{r}}\right.$ IncQ, bem $\left.A:: \operatorname{lac} Z Y A^{\prime}\right)$ and $\mathrm{pUI1098}$ (ZeilstraRyalls \& Kaplan, 1995b) $\left(\mathrm{Sm}^{\mathrm{r}} / \mathrm{Sp}^{\mathrm{r}} \mathrm{Tc}^{\mathrm{r}}\right.$ IncQ, bem $T$ : : lac $\left.Z Y A^{\prime}\right)$ were gifts from Professor S. Kaplan (University of Texas Health Science Center at Houston, USA). These plasmids were transferred from Escherichia coli strain S17-1 (Pro ${ }^{-} \mathrm{Res}^{-} \mathrm{Mod}^{+}$ RecA ${ }^{-}$integrated plasmid RP4-Tc::Mu-Km::Tn7) (Simon et al., 1983) into R. sphaeroides by a patch mating method described by Bonnett $e t$ al. (1995).

Spectroscopic and biochemical analyses. Cultures for spectral analysis were harvested by centrifugation $(7000 \mathrm{~g}$ for $20 \mathrm{~min}$ at $4^{\circ} \mathrm{C}$ ) then resuspended in $5 \mathrm{ml} 20 \mathrm{mM}$ sodium dihydrogen

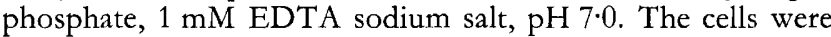
broken by two passages through a French pressure cell $(16000$ p.s.i.; $110 \cdot 4 \mathrm{MPa})$. Cell debris was removed by centrifugation $\left(7000 \mathrm{~g}\right.$ for $15 \mathrm{~min}$ at $\left.4{ }^{\circ} \mathrm{C}\right)$ and the supernatant membranes were pelleted by centrifugation $(145000 \mathrm{~g}$ for $60 \mathrm{~min}$ at $4^{\circ} \mathrm{C}$ ). The membrane fraction was then resuspended in $1 \mathrm{ml}$ phosphate/EDTA buffer. The protein content of membranes was determined by the bicinchoninic acid reagent with BSA as a standard (Smith et al., 1985). Absorbance spectra of membranes from R. sphaeroides were collected on a Hitachi $\mathrm{U}$ 3000 spectrophotometer. From the resulting spectra the concentration of Bch in LH complexes was determined as described by Meinhardt et al. (1984) using $\varepsilon_{\mathrm{mM}}=73$ for LH I at $878-820 \mathrm{~nm}$ and $\varepsilon_{\mathrm{mM}}=96$ for LH II at $849-900 \mathrm{~nm}$. The LH content of membranes was calculated assuming $2 \mathrm{~mol} \mathrm{Bch}$ per mol LH I and $3 \mathrm{~mol} \mathrm{Bch} \mathrm{per} \mathrm{mol} \mathrm{LH} \mathrm{II.} \mathrm{The} \mathrm{total} \mathrm{Bch} \mathrm{values}$ obtained by this spectroscopic method were within $15 \%$ of values for Bch determination after extraction of pigment from membranes using acetone/methanol by the method of Clayton (1966) (data not shown). ALA synthase activity and $\beta$ galactosidase activity were measured in cell-free extracts as described by Burnham (1970) and Clark \& Switzer (1977), respectively. All measurements of enzyme activity and LH content in membranes were performed on three samples for each growth condition. All experiments were performed at least twice. Results are presented as means $\pm \mathrm{sE}$.

\section{RESULTS}

A number of species of phototrophic bacteria are known to respire using $\mathrm{N}_{2} \mathrm{O}$ even though they do not catalyse complete denitrification (McEwan et al., 1985). This was found to be the case for R. sphaeroides strain RS630, which 


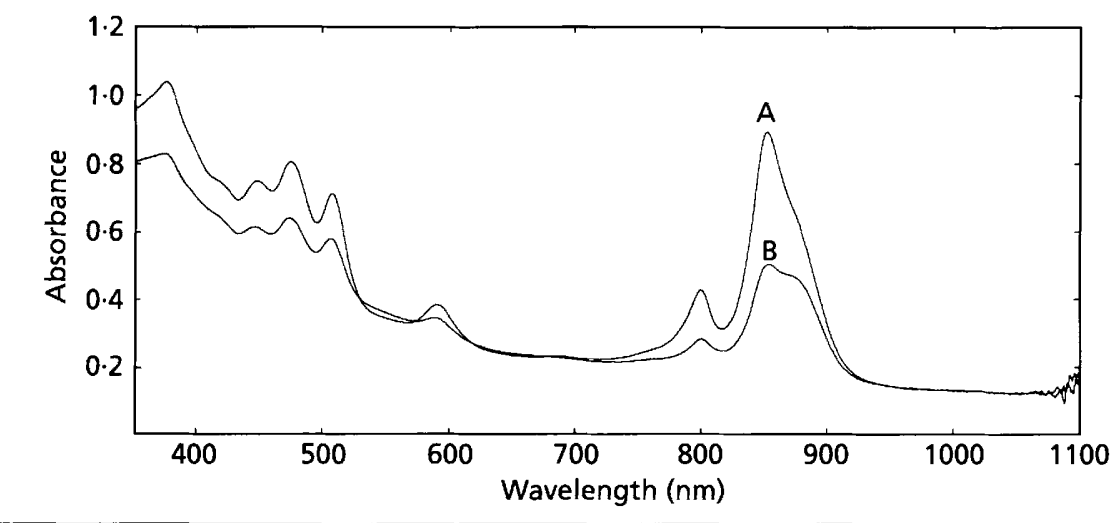

Fig. 1. Absorbance spectra of membranes from $R$. sphaeroides grown phototrophically in the absence (A) and presence (B) of $\mathrm{N}_{2} \mathrm{O}$. Both samples contained $195 \mu \mathrm{g}$ protein.
Table 1. Level of LH complexes and photosynthetic pigments in membranes from cells grown phototrophically in the presence and absence of $\mathrm{N}_{2} \mathrm{O}$

\begin{tabular}{|lrr|}
\hline Growth conditions & \multicolumn{2}{c|}{$\begin{array}{c}\text { Amount [nmol } \\
\text { (mg protein })^{-1} \text { ] of }\end{array}$} \\
\cline { 2 - 3 } & \multicolumn{1}{c}{ LH I } & LH II \\
& \multicolumn{1}{c}{} & \\
\hline $200 \mathrm{~W} \mathrm{~m}^{-2}$ & $10 \cdot 2 \pm 0 \cdot 2$ & $9 \cdot 3 \pm 0 \cdot 1$ \\
$200 \mathrm{~W} \mathrm{~m}^{-2}+\mathrm{N}_{2} \mathrm{O}$ & $6 \cdot 7 \pm 0 \cdot 3$ & $3 \cdot 5 \pm 0 \cdot 3$ \\
$200 \mathrm{~W} \mathrm{~m}^{-2}+$ ferricyanide & $3 \cdot 8 \pm 0 \cdot 2$ & $6 \cdot 0 \pm 0 \cdot 5$ \\
$16 \mathrm{~W} \mathrm{~m}^{-2}$ & $20 \cdot 5 \pm 1 \cdot 2$ & $23 \cdot 2 \pm 0 \cdot 6$ \\
$16 \mathrm{~W} \mathrm{~m}^{-2}+\mathrm{N}_{2} \mathrm{O}$ & $7 \cdot 0 \pm 0 \cdot 2$ & $5 \cdot 4 \pm 0 \cdot 2$ \\
$16 \mathrm{~W} \mathrm{~m}^{-2}+\mathrm{N}_{2} \mathrm{O}+$ ALA & $10 \cdot 6 \pm 1 \cdot 2$ & $10 \cdot 0 \pm 0 \cdot 4$ \\
\hline
\end{tabular}

grew anaerobically in the dark with a doubling time of approximately $8.5 \mathrm{~h}$ on the non-fermentable carbon source malate with $\mathrm{N}_{2} \mathrm{O}$ as sole electron acceptor. The ability of strain RS630 to use $\mathrm{N}_{2} \mathrm{O}$ was confirmed by the demonstration of a reduced methylviologen : $\mathrm{N}_{2} \mathrm{O}$ oxidoreductase activity in cell-free extracts (data not shown). Since it is known that phototrophically growing rhodobacters also utilize respiratory electron acceptors (Jones et al., 1990) a series of experiments was performed to determine whether electron transfer to $\mathrm{N}_{2} \mathrm{O}$ during phototrophic growth influenced PS gene expression.

\section{Effect of $\mathrm{N}_{2} \mathrm{O}$ and ferricyanide on the level of LH complexes in phototrophically grown cells}

Fig. 1 shows the spectra of membranes from cells grown at $200 \mathrm{~W} \mathrm{~m}^{-2}$ (high light intensity). In the sample from cells grown in the absence of $\mathrm{N}_{2} \mathrm{O}$, the $875 \mathrm{~nm} \mathrm{Bch}$ absorbance band of LH I can be seen as a poorly defined shoulder on the $850 \mathrm{~nm}$ Bch absorbance band of the LH II complex. In membranes from cells grown at the same light intensity in the presence of $\mathrm{N}_{2} \mathrm{O}$ the $\mathrm{LH}$ I peak at $875 \mathrm{~nm}$ was almost equal in magnitude to the LH II peak at $850 \mathrm{~nm}$, indicating a marked decrease in the LH II content of these membranes. Quantification of the level of LH II and LH I complexes in the photosynthetic membranes from cells grown at high light intensity is shown in Table 1 . An approximately $30 \%$ decrease and a
$60 \%$ decrease in the level of LH I and LH II complexes, respectively, was caused by the presence of $\mathrm{N}_{2} \mathrm{O}$. As a result, in membranes from $\mathrm{N}_{2} \mathrm{O}$-grown cells the $\mathrm{LH}$ I/LH II ratio was about double that found in membranes from cells grown in the absence of $\mathrm{N}_{2} \mathrm{O}$.

A lowering in light intensity triggers an increase in the levels of LH complexes, particularly LH II (Aagard \& Sistrom, 1972). To determine whether $\mathrm{N}_{2} \mathrm{O}$ affected the induction of L.H complexes in response to a decrease in light intensity, R. sphaeroides was grown at $16 \mathrm{~W} \mathrm{~m}^{-2}$ (low light intensity) and spectra of membranes prepared from these cells were collected. The increased level of LH complexes in membranes from low light grown cells compared to those from cells grown at high light is illustrated in Table 1. The results in Table 1 also show that, as for the cells grown at high light intensity, $\mathrm{N}_{2} \mathrm{O}$ caused a dramatic lowering in the level of LH complexes in cells grown at low light intensity, with an approximately $65 \%$ decrease in $\mathrm{LH}$ I and a $75 \%$ decrease in $\mathrm{LH}$ II being observed. It can also be seen that membranes from low light grown cells had twice the level of LH I compared to those from high light grown cells but in membranes from cells grown with $\mathrm{N}_{2} \mathrm{O}$ there was virtually no change in the level of $\mathrm{LH} \mathrm{I}$ as a function of light intensity (Table 1). Cells grown at low light intensity had about 2.5 times the level of LH II compared to cells grown at high light intensity, but the presence of $\mathrm{N}_{2} \mathrm{O}$ resulted in the level only being about 1.5 -fold higher. Inspection of the spectra in Fig. 1 shows that Crt levels (absorbance peaks between $450 \mathrm{~nm}$ and $530 \mathrm{~nm}$ ) also changed in parallel with those of the Bch component of the LH complexes. Although the Crt content of LH complexes was not analysed in detail, this is taken to indicate that $\mathrm{N}_{2} \mathrm{O}$ was affecting the level of the LH complexes in photosynthetic membranes and was probably not causing a major change in their composition.

It is established that $\mathrm{N}_{2} \mathrm{O}$ reductase takes electrons from cytochrome $c_{2}$ (Richardson et al., 1991) and this led us to test whether other oxidants of cytochrome $c_{2}$ could affect PS gene expression. Ferricyanide was used, and it was found that the presence of this oxidant during phototrophic growth caused a lowering of both LH I and LH II levels in cells grown at high light intensity, with the level of LH I being lowered to a greater degree than that of LH II. However, it should be noted that ferricyanide 
Table 2. $\beta$-Galactosidase activity in cell extracts of $R$. sphaeroides bearing lacZ transcriptional fusions grown phototrophically at high light intensity in the presence and absence of $\mathrm{N}_{2} \mathrm{O}$

\begin{tabular}{|c|c|c|c|c|}
\hline \multirow[t]{2}{*}{$\begin{array}{l}\text { Growth } \\
\text { conditions }\end{array}$} & \multicolumn{4}{|c|}{$\begin{array}{c}\beta \text {-Galactosidase activity } \\
{\left[\text { nmol ONPG hydrolysed } \min ^{-1}(\mathrm{mg} \text { protein })^{-1}\right]}\end{array}$} \\
\hline & puf-lacZ & puc-lacZ & hemA-lac Z & hemT-lacZ \\
\hline $200 \mathrm{~W} \mathrm{~m}^{-2}$ & $4000 \pm 200$ & $4800 \pm 500$ & $4300 \pm 90$ & $180 \pm 20$ \\
\hline $200 \mathrm{~W} \mathrm{~m} \mathrm{~m}^{-2}+\mathrm{N}_{2} \mathrm{O}$ & $3400 \pm 200$ & $7800 \pm 300$ & $1400 \pm 240$ & $310 \pm 20$ \\
\hline
\end{tabular}

caused R. sphaeroides to grow more slowly and to a lower culture density than in the other growth conditions shown in Table 1. At low light intensity the effect of ferricyanide on growth was even more severe and this prevented measurement of LH levels.

\section{Partial suppression of the $\mathrm{N}_{2} \mathrm{O}$ effect by ALA}

The first step in haem and Bch biosynthesis, catalysed by ALA synthase, has been recognized for many years as a potential control point in the Bch biosynthetic pathway and it is known that the addition of ALA to the culture medium can restore photosynthetic competence to mutants that are unable to synthesize ALA (Lascelles \& Altshuler, 1969; Neidle \& Kaplan, 1993a). Table 1 also shows the effect of ALA on LH levels in R. sphaeroides grown phototrophically at low light intensity in the presence of $\mathrm{N}_{2} \mathrm{O}$. There was a decrease in the level of $\mathrm{LH}$ complexes in cells grown with $\mathrm{N}_{2} \mathrm{O}$ but the presence of ALA partially suppressed this effect, elevating the level of both LH I and LH II (Table 1). The presence of ALA had no effect on the level of LH I and only slightly raised the level of LH II in cells grown in the absence of $\mathrm{N}_{2} \mathrm{O}$ (data not shown).

R. sphaeroides possesses two ALA synthase enzymes which both catalyse the condensation of succinyl-CoA and glycine (Neidle \& Kaplan, 1993b). The total ALA synthase activity was $2.5 \pm 0 \cdot 2 \mathrm{nmol} \mathrm{ALA} \mathrm{formed} \mathrm{h}^{-1}$ (mg protein $)^{-1}$ and $2 \cdot 2 \pm 0 \cdot 3 \mathrm{nmol}$ ALA formed $\mathrm{h}^{-1}$ (mg protein $)^{-1}$ in extracts from cells grown phototrophically in the presence of $\mathrm{N}_{2} \mathrm{O}$ at low light and high light, respectively. This compared to $9 \cdot 2 \pm 0 \cdot 1 \mathrm{nmol}$ ALA formed $\mathrm{h}^{-1}$ (mg protein $)^{-1}$ (low light) and $5 \cdot 2 \pm 0 \cdot 1 \mathrm{nmol}$ ALA formed $\mathrm{h}^{-1}$ (mg protein) ${ }^{-1}$ (high light) in extracts from cells grown phototrophically without the electron acceptor.

\section{Effect of $\mathrm{N}_{2} \mathrm{O}$ on expression of the puf, puc, hemA and hemT operons}

The results described above clearly showed that levels of both LH complexes were lower during phototrophic growth of cells in the presence of $\mathrm{N}_{2} \mathrm{O}$. This raised the question of whether the effect of $\mathrm{N}_{2} \mathrm{O}$ was exerted at the level of transcription of the $p u f$ and $p u c$ operons or at other stages in the formation of LH complexes. To address this,
Table 3. Level of light-harvesting complexes in membranes from cells grown in the dark with oxygen or DMSO or $\mathrm{N}_{2} \mathrm{O}$ as electron acceptor

\begin{tabular}{|c|c|c|}
\hline \multirow[t]{2}{*}{$\begin{array}{l}\text { Electron } \\
\text { acceptor }\end{array}$} & \multicolumn{2}{|c|}{$\begin{array}{c}\text { Amount [nmol } \\
\left.(\mathrm{mg} \text { protein })^{-1}\right] \text { of }\end{array}$} \\
\hline & LH I & LH II \\
\hline Oxygen & $1 \cdot 3 \pm 0 \cdot 3$ & $0 \cdot 4 \pm 0 \cdot 1$ \\
\hline $\mathrm{N}_{2} \mathrm{O}$ & $2 \cdot 8 \pm 0.5$ & $1.9 \pm 0.4$ \\
\hline DMSO & $9 \cdot 1 \pm 0.5$ & $9.5 \pm 0.5$ \\
\hline
\end{tabular}

the effect of $\mathrm{N}_{2} \mathrm{O}$ on the activity of $p u f-l a c Z$ and $p u c-l a c Z$ fusions in R. sphaeroides grown phototrophically at high light intensity was investigated. The $\beta$-galactosidase activity of the puf-lac $Z$ fusion was lower in extracts from cells grown in the presence of $\mathrm{N}_{2} \mathrm{O}$ than in those grown in its absence (Table 2). This correlates positively with the level of LH I complex in cells grown under the same conditions (Table 1). The pattern of $\beta$-galactosidase activity in cells expressing the puc-lac $Z$ fusion was quite different and was higher in the extracts from cells grown in the presence of $\mathrm{N}_{2} \mathrm{O}$ (Table 2). The expression of the bem $A$-lac $Z$ fusion was reduced by about threefold by the presence of $\mathrm{N}_{2} \mathrm{O}$ during phototrophic growth of $\mathrm{R}$. sphaeroides (Table 2). In contrast, the pattern of expression of the bem T-lac $Z$ fusion resembled that of the puc-lacZ fusion and the level of $\beta$-galactosidase activity was higher in cells grown with $\mathrm{N}_{2} \mathrm{O}$ (Table 2).

\section{Level of LH complexes in cells grown in the dark with oxygen, $\mathrm{N}_{2} \mathrm{O}$ and DMSO as electron acceptors}

Gratuitous synthesis of the photosynthetic apparatus occurs under anaerobic dark conditions and this has proved to be particularly valuable for analysis of photosynthetically incompetent mutants (Eraso \& Kaplan, 1995). DMSO has been the electron acceptor most widely used and it was found that strain RS630 could grow anaerobically in the dark with DMSO as electron acceptor and malate as carbon source. The levels of LH complexes in membranes from cells grown under anaerobic dark conditions with DMSO or $\mathrm{N}_{2} \mathrm{O}$ as electron acceptor are shown in Table 3. Cells grown on $\mathrm{N}_{2} \mathrm{O}$ contained about 
threefold less LH I and about fourfold less LH II than cells grown with DMSO. This resulted in LH I/LH II ratios of 0.9 for DMSO-grown cells and 1.5 for $\mathrm{N}_{2} \mathrm{O}$ grown cells. Although the level of LH complexes was low in cells grown with $\mathrm{N}_{2} \mathrm{O}$, it was higher than that found for cells grown aerobically in the dark (Table 3 ).

\section{DISCUSSION}

A problem with investigating the effects of oxygen on gene expression is that this oxidant can exert an effect via a variety of direct and indirect mechanisms (reviewed by Unden et al., 1995). In order to overcome this problem we used two electron acceptors of anaerobic respiration, $\mathrm{N}_{2} \mathrm{O}$ and DMSO. The data described in this paper show that the presence of the respiratory electron acceptor $\mathrm{N}_{2} \mathrm{O}$ during phototrophic (anaerobic) growth of $\mathrm{R}$. sphaeroides causes a marked reduction in the level of LH complexes. The simplest explanation for the data is that a redox change induced by $\mathrm{N}_{2} \mathrm{O}$ respiration acts as a signal which leads to a reduced level of LH complexes.

The expression of PS genes in R. sphaeroides is now very well documented. For many years a key regulatory step in Bch synthesis has been known to be ALA synthase and it is established that this can occur both at the level of enzyme activation/deactivation (Clement-Metral, 1979) and at the level of gene expression (Neidle \& Kaplan, 1993b). The situation in $R$. sphaeroides is complicated by the presence of two genes encoding ALA synthase, hem $A$ and bem $T$ (Neidle \& Kaplan, 1993a, b). The effect of $\mathrm{N}_{2} \mathrm{O}$ on phototrophically grown cells was to significantly reduce the activity of ALA synthase in the cell but this experiment did not identify whether one or both types of ALA synthase was affected. The reduction in total ALA synthase activity limited production of Bch pigment complexes since addition of ALA at least partially restored the level of Bch pigment to that observed in the absence of $\mathrm{N}_{2} \mathrm{O}$. The production of ALA is a highly sensitive control point and this probably arises because the $K_{\mathrm{m}}$ of ALA dehydratase is $700 \mu \mathrm{M}$ (Shemin, 1972) and as a result the flux via the Bch pathway may be highly dependent on the intracellular level of ALA.

Our results indicate that a decrease in ALA synthase activity caused by the presence of $\mathrm{N}_{2} \mathrm{O}$ during phototrophic growth is correlated with a decrease in bem $A$ expression under the same conditions. bem $A$ expression has been shown to be under control of FnrL, a homologue of the regulator of anaerobic gene expression in $E$. coli (Zeilstra-Ryalls \& Kaplan, 1995a). This leads us to suggest that redox changes elicited by $\mathrm{N}_{2} \mathrm{O}$ respiration may affect FnrL activity. It has also been shown that Fnrbinding consensus sequences are present in upstream sequences of $b c b E$ and other genes which may be involved in PS gene expression (Zeilstra-Ryalls \& Kaplan, 1995a). Hence, the failure of ALA to completely restore the Bch levels to that seen in cells grown in the absence of $\mathrm{N}_{2} \mathrm{O}$ can be explained if redox changes induced by $\mathrm{N}_{2} \mathrm{O}$ exert an effect on the FnrL-dependent expression of genes encoding enzymes in the Bch pathway in addition to bem $A$. Since $\mathrm{N}_{2} \mathrm{O}$ reductase takes electrons from peri- plasmic cytochrome $c_{2}$ (Richardson et al., 1991) and ferricyanide, a membrane-impermeable oxidant, is also thought to oxidize cytochrome $c_{2}$ then it seems likely that in $R$. sphaeroides a redox signal elicited by these oxidants needs to be transduced across the cytoplasmic membrane. Support for the view that FnrL may respond to redox changes comes from the observation that $R$. sphaeroides cco mutants, which lack a $c b$-type cytochrome oxidase, exhibit increased expression of FnrL-dependent genes in the presence of oxygen (Zeilstra-Ryalls \& Kaplan, 1996). This result is consistent with our observations since it is expected that the $c b$-type cytochrome oxidase will oxidize periplasmic cytochrome $c_{2}$.

Recent results of Kiley and co-workers have established that Fnr from E. coli probably contains one $4 \mathrm{Fe}-4 \mathrm{~S}$ cluster per monomer (Lazazzera $e t$ al., 1996). The active form of Fnr is a dimer (Ziegelhoffer \& Kiley, 1995) and there is now evidence that the extreme oxygen lability of the $\mathrm{Fe}-\mathrm{S}$ cluster is associated with monomer formation and decreased ability to bind DNA (Lazazzera et al., 1996). Although these results support the view that Fnr responds to an oxygen species directly, there is evidence that even in E. coli redox reactions also influence its activity. Unden et al. (1990) showed that, under anoxic conditions, positive redox potentials $(>+440 \mathrm{mV}$ at $\mathrm{pH} 7 \cdot 0)$ were sufficient to decrease Fnr-dependent expression of an frd-lac $Z$ fusion in $E$. coli. Although $E$. coli has rather different pathways of aerobic respiration compared to $R$. sphaeroides (Garcia-Horsman et al., 1994) the two bacterial species do possess some homologous redox proteins. $R$. sphaeroides possesses two genes, $r d x A$ and $r d x B$, which each encode a predicted transmembrane protein containing four 4Fe-4S clusters (Neidle \& Kaplan, 1992; Zeilstra-Ryalls \& Kaplan, 1996). Rdx proteins are homologous to NapG in $E$. coli and proteins of this family are found in a number of facultative aerobes (Berks et al., 1995).

The $r d x B H I S$ operon, bem $A$ operon and $c c o$ operon in $\mathrm{R}$. sphaeroides all have Fnr-binding consensus sequences and are located in a gene cluster which also contains fnrL (Zeilstra-Ryalls \& Kaplan, 1996). The recent observation that FnrL-dependent gene expression was increased in cells lacking the $c b$-type cytochrome oxidase has led to a proposal that redox activation of FnrL occurs under conditions of low oxygen tension and that this process may involve Rdx (Zeilstra-Ryalls \& Kaplan, 1996). The only established function of $\mathrm{RdxA}$ in $\mathrm{R}$. sphaeroides is in the reduction of tellurite to tellurium metal (Neidle \& Kaplan, 1992). Since this process is also dependent upon cytochrome $c_{2}$ and cytochrome $b c_{1}$ it suggests that $\mathrm{Rdx}$ may interact with the respiratory chain via these components (Moore \& Kaplan, 1992). If a pathway of electron transport involving cytochrome $c_{2}$, the cytochrome $b c_{1}$ complex and $\mathrm{Rdx}$ was involved in a direct or indirect redox interaction with FnrL then the effect of respiratory oxidants such as oxygen and $\mathrm{N}_{2} \mathrm{O}$ on FnrL activity could be explained as a diversion of electrons away from the $\mathrm{Rdx}$ pathway. This model would also explain why $R$. sphaeroides growing under phototrophic or anaerobic dark conditions with DMSO as electron acceptor synthesizes higher levels of $\mathrm{LH}$ complex than those grown with $\mathrm{N}_{2} \mathrm{O}$ 
as electron acceptor; electron transfer to DMSO does not involve the cytochrome $b c_{1}$ complex or cytochrome $c_{2}$ but branches from the cyclic photosynthetic electron transfer pathway at the level of the ubiquinone pool (Q-pool) (McEwan, 1994). As a result, cytochrome $c_{2}$ would be expected to be more reduced in cells growing with DMSO than in those cells growing in the presence of $\mathrm{N}_{2} \mathrm{O}$, and this has been observed for dark anaerobic cells of R. capsulatus (Jones et al., 1990). The situation in E. coli is slightly different from that of $R$. sphaeroides but since the Fnr-regulated nap $/ \mathrm{cm}$ gene cluster, formerly known as the aeg-46.5 cluster, encodes $c$-type cytochromes and periplasmic nitrate reductase, as well as NapG (Groves $e t$ al., 1996), the possibility that respiratory electron transport is in redox communication with Fnr needs to be considered.

The effect of $\mathrm{N}_{2} \mathrm{O}$ expression on the puf-lac $Z$ and puc-lac $Z$ fusions in phototrophically grown cells shows that both of these operons are subject to redox control. The mechanisms which control puf operon expression are still unclear but certainly its expression is highly responsive to Bch availability and this may arise as a result of decreased ALA synthase activity (Neidle \& Kaplan, 1993a). The increase in the level of $p u c-l a c Z$ expression in cells grown in the presence of $\mathrm{N}_{2} \mathrm{O}$ may seem surprising in view of the fact the level of mature LH II was lower under the same conditions. However, the relationship between the level of puc transcripts and LH II level in Rbodobacter is known to be complex. Zucconi \& Beatty (1988) have shown that the level of the $0.5 \mathrm{~kb}$ puc mRNA was about four times higher in $R$. capsulatus cells grown at $140 \mathrm{~W} \mathrm{~m}^{-2}$ compared to those grown at $2 \mathrm{~W} \mathrm{~m}^{-2}$, which is in contrast to the level of mature LH II. It is interesting that Neidle \& Kaplan (1993b) reported that in a bem $T$ mutant both puc and puf transcripts were higher than in wild-type cells, even though the level of $\mathrm{LH}$ complexes was lower. The control of bem $T$ expression is quite different from bem $A$ (Neidle \& Kaplan, 1993a, b) and this was also reflected in the change in expression of bem $T$ in response to $\mathrm{N}_{2} \mathrm{O}$. The apparent increase in the expression of bem $T$ cannot be explained but the data suggest that the expression of bem $T$ and $p u c$ may be subject to a similar control mechanism.

Although we can explain some of the effects of $\mathrm{N}_{2} \mathrm{O}$ respiration on PS gene expression in terms of regulation by FnrL, the unusual regulation of bem $T$ and puc expression suggests that another signal transduction pathway may be affected by $\mathrm{N}_{2} \mathrm{O}$. A key observation regarding the effect of $\mathrm{N}_{2} \mathrm{O}$ on phototrophically growing cells was that, although $\mathrm{N}_{2} \mathrm{O}$ affected the level of LH I, one of its major effects was to prevent the increase in the level of LH II that occurs when cells are grown at low light intensity. This situation resembles that of a reg mutant in $R$. capsulatus which makes reduced amounts of LH complex compared to wild-type cells and cannot increase the synthesis of $\mathrm{LH}$ complexes in response to low light intensities (Sganga \& Bauer, 1992). The Reg system of $R$. capsulatus and its counterpart, Prr, in R. sphaeroides is a sensor histidine kinase reponse regulator which acts as an activator of PS gene expression (Eraso \& Kaplan, 1994, 1995), although its action is probably indirect since the response regulator, $\operatorname{Pr} A$, is not a DNA-binding protein. A third protein, PrrC, seems to modulate the activity of the PrrB sensor kinase (Eraso \& Kaplan, 1995) and it is known that this membrane protein has a periplasmic domain and a predicted $\mathrm{Fe}-\mathrm{S}$ cluster (Buggy \& Bauer, 1995). We suggest that the PrrB kinase is influenced by changes in the redox state of cytochrome $c_{2}$, possibly working via PrrC, and that this affects PS gene expression. In this model, the maintenance of cytochrome $c_{2}$ in a relatively oxidized state during phototrophic growth in the presence of $\mathrm{N}_{2} \mathrm{O}$ would result in lowered PrrB activity and decreased PS gene expression.

\section{ACKNOWLEDGEMENTS}

We are grateful to Professor Sam Kaplan and Dr Jill ZeilstraRyalls for the provision of the lac fusions used in this study and for valuable discussions.

\section{REFERENCES}

Aagard, J. \& Sistrom, W. R. (1972). Control of synthesis of reaction center bacteriochlorophyll in Rhodopseudomonas sphaeroides. Photochem Photobiol 15, 209-225.

Berks, B. C., Ferguson, S. J., Moir, J. W. B. \& Richardson, D. J. (1995). Enzymes and associated electron transport systems that catalyse the reduction of nitrogen oxides and oxyanions. Biochim Biophys Acta 1232, 97-173.

Bonnett, T. C., Cobine, P., Sockett, R. E. \& McEwan, A. G. (1995). Phenotypic characterization and genetic complementation of dimethylsulfoxide respiratory mutants of Rhodobacter sphaeroides and Rhodobacter capsulatus. FEMS Microbiol Lett 133, 163-168.

Buggy, J. \& Bauer, C. E. (1995). Cloning and characterization of $\operatorname{sen} C$, a gene involved in both aerobic respiration and photosynthesis gene expression in Rhodobacter capsulatus. J Bacteriol 177, 6958-6965.

Buggy, J. J., Sganga, M. W. \& Bauer, C. E. (1994). Characterisation of a light responding trans-activator responsible for differentially controlling reaction center and light-harvesting I gene expression in Rbodobacter capsulatus. J Bacteriol 176, 6936-6943.

Burnham, B. F. (1970). 5-aminolevulinic acid synthase. Methods Enzymol 17, 195-204.

Clark, J. M., Jr \& Switzer, R. L. (1977). Experimental Biochemistry. p. 97. San Francisco: W. H. Freeman.

Clayton, R. K. (1966). Spectroscopic analysis of bacteriochlorophylls in vitro and in vivo. Photochem Photobiol 5, 669-677.

Clayton, R. K. (1970). Light and Living Matter, vol. 1, The Physical Part. New York: McGraw-Hill.

Clement-Metral, J. D. (1979). Activation of ALA synthase by reduced thioredoxin in Rhodopseudomonas sphaeroides Y. FEBS Lett 101, 116-120.

Cohen-Bazire, G., Sistrom, W. R. \& Stanier, R. Y. (1957). Kinetic studies of pigment synthesis by non-sulfur purple bacteria. $J$ Cell Comp Physiol 49, 25-68.

Eraso, J. M. \& Kaplan, S. (1994). $\operatorname{prr} A$, a putative response regulator involved in oxygen regulation of photosynthesis gene expression in Rhodobacter sphaeroides. J Bacteriol 177, 2695-2706.

Eraso, J. M. \& Kaplan, S. (1995). Oxygen-insensitive synthesis of photosynthetic membranes of Rhodobacter sphaeroides: a mutant histidine kinase. J Bacteriol 177, 2695-2706.

Ferguson, S. J., Jackson, J. B. \& McEwan, A. G. (1987). Anaerobic respiration in the Rhodospirillaceae: characterisation of pathways and 
evaluation of roles in redox balancing during photosynthesis. FEMS Microbiol Rev 46, 117-143.

Garcia-Horsman, J. A., Barquera, B., Rumbley, J., Ma, J. \& Gennis, R. B. (1994). The superfamily of heme-copper respiratory oxidases. $J$ Bacteriol 176, 5587-5600.

Gomelsky, M. \& Kaplan, S. (1995). Genetic evidence that PpsR from Rbodobacter sphaeroides 2.4 .1 functions as a repressor of puc and $b c b F$ expression. J Bacteriol 177, 1634-1637.

Groves, J., Tanapongpipat, S., Thomas, G., Griffiths, L., Crooke, H. \& Cole, J. (1996). Eschericbia coli $\mathrm{K}-12$ genes essential for the synthesis of $c$-type cytochromes and a third nitrate reductase located in the periplasm. Mol Microbiol 19, 467-481.

Hunter, C. N., McGlynn, P., Ashby, M. K., Burgess, J. G. \& Olsen, J. D. (1991). DNA sequencing and complementation analysis of the bch $A$-puf operon of Rhodobacter sphaeroides: in vivo mapping of the oxygen-regulated puf promoter. Mol Microbiol 5, 2649-2661.

Jones, M. R., Richardson, D. J., McEwan, A. G., Ferguson, S. J. \& Jackson, J. B. (1990). In vivo redox poising of the cyclic electron transport system of Rhodobacter capsulatus and the effects of the auxiliary oxidants nitrate, nitrous oxide and trimethylamine- $N$ oxide as revealed by multiple short flash excitation. Biochim Biopbys Acta 1017, 209-216.

Kiley, P. J. \& Kaplan, S. (1987). Cloning, DNA sequence, and expression of the Rhodobacter sphaeroides B800-850 a and B800-850 b genes. J Bacteriol 169, 3268-3275.

Kiley, P. J. \& Kaplan, S. (1988). Molecular genetics of photosynthetic membrane biosynthesis in Rhodobacter sphaeroides. Microbiol Rev 52, 50-69.

Kiley, P. J., Donohue, T. J., Havelka, W. A. \& Kaplan, S. (1987). DNA sequence and in vitro expression of the B875 light-harvesting polypeptides of Rhodobacter sphaeroides. J Bacteriol 169, 742-750.

Klug, G. (1993). The role of mRNA degradation in the regulated expression of bacterial photosynthesis genes. Mol Microbiol 9, 1-7.

Lascelles, J. \& Altshuler, T. (1969). Mutant strains of Rhodopseudomonas sphaeroides lacking $\delta$-aminolevulinate synthase: growth, heme, and bacteriochlorophyll synthesis. J Bacteriol 98, 721-727.

Lazazzera, B. A., Beinert, H., Khoroshilova, N., Kennedy, M. C. \& Kiley, P. J. (1996). DNA binding and dimerization of the $\mathrm{Fe}-\mathrm{S}$ containing FNR protein from Escherichia coli are regulated by oxygen. J Biol Chem 271, 2762-2768.

Lee, J. K. \& Kaplan, S. (1992). cis-Acting regulatory elements involved in oxygen regulation of puc operon transcription in Rhodobacter sphaeroides. J Bacteriol 174, 1158-1171.

Lee, J. K., Kiley, P. J. \& Kaplan, S. (1989). Posttranscriptional control of puc operon expression of B800-850 light-harvesting complex formation in Rhodobacter sphaeroides. J Bacteriol 171, 3391-3405.

McEwan, A. G. (1994). Photosynthetic electron transport and anaerobic metabolism in purple non-sulfur phototrophic bacteria. Antonie Leewvenboek 66, 151-164.

McEwan, A. G., Greenfield, A. J., Wetzstein, H. G., Jackson, J. B. \& Ferguson, S. J. (1985). Nitrous oxide respiration by members of the family Rhodospirillaceae and the nitrous oxide reductase of Rhodopseudomonas capsulata. J Bacteriol 164, 823-830.

Meinhardt, S. W., Kiley, P. J., Kaplan, S., Crofts, A. R. \& Harayama, S. (1984). Characterization of light-harvesting mutants of $R$ bodopseudomonas sphaeroides. I. Measurement of the efficiency of energy transfer from the light-harvesting complexes to the reaction centre. Arch Biochem Biophys 236, 130-139.

Michalski, W. P. \& Nicholas, D. J. D. (1987). Inhibition of bacteriochlorophyll synthesis in Rbodobacter sphaeroides subsp. denitrificans in light under denitrifying conditions. J Bacteriol 169, 4651-4659.
Michalski, W. P., Nicholas, D. J. D. \& Whatley, F. R. (1985). Effects of nitrate, nitrite and diphenylamine on the photosynthetic apparatus of Rhodopseudomonas sphaeroides $\mathrm{f}$. sp. denitrificans. J Gen Microbiol 131, 1951-1961.

Moore, M. D. \& Kaplan, S. (1992). Identification of intrinsic highlevel resistance to rare-earth oxides and oxyanions in members of the class Proteobacteria: characterization of tellurite, selenite and rhodium sesquioxide reduction in Rhodobacter sphaeroides. J Bacteriol 174, 1505-1514.

Neidle, E. L. \& Kaplan, S. (1992). Rhodobacter sphaeroides $r d x A$, a homolog of Rbizobium meliloti fix $G$, encodes a membrane protein which may bind cytoplasmic [4Fe-4S] clusters. J Bacteriol 174, 6444-6454.

Neidle, E. L. \& Kaplan, S. (1993a). 5-Aminolevulinic acid availability and control of spectral complex formation in HemA and Hem T mutants of Rhodobacter spbaeroides. J Bacteriol 175, 2304-2313.

Neidle, E. L. \& Kaplan, S. (1993b). Expression of the Rhodobacter sphaeroides bem $A$ and bem $T$ genes, encoding two 5-aminolevulinic acid synthase enzymes. J Bacteriol 175, 2292-2303.

Pemberton, J. M. \& Bowen, A. R. St G. (1981). High frequency chromosome transfer in Rhodopseudomonas sphaeroides promoted by the broad host range plasmid RP1 carrying the mercury transposon Tn501. J Bacteriol 161, 469-472.

Penfold, R. J. \& Pemberton, J. M. (1991). A gene from the photosynthetic gene cluster of Rhodobacter sphaeroides induces trans suppression of bacteriochlorophyll and carotenoid levels in $R$. sphaeroides and R. capsulatus. Curr Microbiol 23, 259-263.

Penfold, R. J. \& Pemberton, J. M. (1994). Sequencing, chromosomal inactivation, and functional expression in Escherichia coli of $p p s \mathrm{R}$, a gene which represses carotenoid and bacteriochlorophyll synthesis in Rhodobacter sphaeroides. J Bacteriol 176, 2869-2876.

Richardson, D. J., Bell, L. C., McEwan, A. G., Jackson, J. B. \& Ferguson, S. J. (1991). Cytochrome $c_{2}$ is essential for electron transfer to nitrous oxide reductase from physiological substrates in Rhodobacter capsulatus and can act as an electron donor in vitro. Eur J Biochem 199, 677-683.

Sambrook, J., Fritsch, E. F. \& Maniatis, T. (1989). Molecular Cloning: a Laboratory Manual, 2nd edn. Cold Spring Harbor, NY: Cold Spring Harbor Laboratory.

Sganga, M. W. \& Bauer, C. E. (1992). Regulatory factors controlling photosynthetic reaction center and light-harvesting gene expression in Rhodobacter capsulatus. Cell 68, 945-954.

Shemin, D. (1972). $\delta$-Aminolevulinic acid dehydratase. In The Enzymes, vol. VII, pp. 323-338. Edited by P. D. Boyer. New York: Academic Press.

Simon, R., Priefer, U. \& Puhler, A. (1983). A broad host range mobilization system for in vivo genetic engineering: transposon mutagenesis in gram negative bacteria. Bio/Technology 1, 784-791.

Smith, P. K., Krohn, R. I., Hermanson, G. T., Mallia, A. K., Gartner, F. H., Provenzano, M. D., Fujimoto, E. K., Goeke, N. M., Olson, B. J. \& Klenk, D. C. (1985). Measurement of protein using bicinchoninic acid. Anal Biochem 150, 76-85.

Unden, G., Trageser, M. \& Duchene, A. (1990). Effect of positive redox potentials $(>+400 \mathrm{mV})$ on the expression of anaerobic respiratory enzymes in Escherichia coli. Mol Microbiol 4, 315-319.

Unden, G., Becker, S., Bongaerts, J., Holighaus, G., Schirawski, J. \& Six, S. (1995). $\mathrm{O}_{2}$-sensing and $\mathrm{O}_{2}$-dependent gene regulation in facultatively anaerobic bacteria. Arch Microbiol 164, 81-90.

Weaver, P. F., Wall, J. D. \& Gest, H. (1975). Characterization of Rhodopseudomonas capsulata. Arch Microbiol 105, 207-216.

Williams, J. C., Steiner, L. A., Ogden, R. C., Simon, M. I. \& Feher, G. (1983). Primary structure of the $M$ subunit of the reaction center 
of Rbodopseudomonas sphaeroides. Proc Natl Acad Sci USA 80, 6595-6609.

Williams, J. C., Steiner, L. A., Feher, G. \& Simon, M. I. (1984).

Primary structure of the $\mathrm{L}$ subunit of the reaction center of Rbodopseudomonas spbaeroides. Proc Natl Acad Sci USA 81, $7303-7308$

Wu, Y. Q., MacGregor, B. J., Donohue, T. J., Kaplan, S. \& Yen, B. (1991). Genetic and physical mapping of the Rbodobacter spbaeroides photosynthetic gene cluster from R-prime pWS2. Plasmid 25, 163-176.

Zeilstra-Ryalls, J. \& Kaplan, S. (1995a). Aerobic and anaerobic regulation in Rbodobacter sphaeroides 2.4 .1 : the role of the fnr $L$ gene. $J$ Bacteriol 177, 6422-6431.

Zeilstra-Ryalls, J. \& Kaplan, S. (1995b). Regulation of 5- aminolevulinic acid synthesis in Rbodobacter sphaeroides 2.4 .1 : the genetic basis of mutant H-5 auxotrophy. J Bacteriol 177, 2760-2768.

Zeilstra-Ryalls, J. \& Kaplan, S. (1996). Control of bem $A$ expression in $R$ bodobacter sphaeroides 2.4 .1 : regulation through alterations in the cellular redox state. J Bacteriol 178, 985-993.

Ziegelhoffer, E. C. \& Kiley, P. J. (1995). In vitro analysis of a constitutively active mutant form of the Escherichia coli global transcription factor FNR. I Mol Biol 245, 351-361.

Zucconi, A. \& Beatty, J. T. (1988). Post-transcriptional regulation by light of the steady state levels of mature B800-850 lightharvesting complexes in Rhodobacter capsulatus. I Bacteriol 170, $877-882$.

Received 20 March 1996; revised 7 June 1996; accepted 17 June 1996. 